JKT, 2018;9(2):77-86. Kompetensi Perawat dan Patient Safety di RSUD Piru. ... Irhamdi Achmad

\title{
KOMPETENSI PERAWAT DAN PATIENT SAFETY DI RSUD PIRU KABUPATEN SERAM BAGIAN BARAT
}

Nurse Competence and Patient Safety in Piru Hospital Seram Bagian Barat District

\section{Irhamdi Achmad ${ }^{1}$}

${ }^{1}$ Program Studi Keperawatan Masohi Poltekkes Kemenkes Maluku, Jalan Trans Seram, Letwaru, Kota Masohi, Kabupaten Maluku Tengah, Maluku

E-mail: irhamdi_maulana@yahoo.com

\begin{abstract}
Patient safety in hospitals is a global issue and it is important to establish a safer and more comfortable system of nursing and health services in hospitals. Nursing care is expected to be of good quality and useful in preventing incidents of unwanted events that can harm patients and hospitals. The reality in the hospital even though the socialization and training of patient safety have been carried out by the hospital to nurses and health workers there are still cases of injured patients, patients falling and wrong treatment. This study aims to determine the relationship of nurse competencies that was nursing studies, nursing ethics, drug administration and measurement of vital signs with patient safety in Piru Hospital in 2017. The type of research is descriptive analytic with design cross-sectional. The instrument used was a questionnaire, with a sample of 66 nurses at the Piru Hospital in Seram Bagian Barat District. The results showed that there was a relationship between significant nursing assessment competencies, nursing ethics, administration of drugs and the measurement of vital signs with patient safety, at the Piru Hospital. Therefore nurses' knowledge and technical skills regarding patient safety through various socialization and training activities must be improved so that the safety and security of patients in hospital services is guaranteed and the hospital image becomes better.
\end{abstract}

Keywords: Nurse competence, patient safety, hospital

\begin{abstract}
ABSTRAK
Keselamatan pasien (patient safety) di rumah sakit merupakan isu global dan penting untuk membentuk sistem pelayanan keperawatan dan kesehatan di rumah sakit menjadi lebih aman dan nyaman. Diharapkan asuhan keperawatan yang diberikan berkualitas dan bermanfaat dalam mencegah insiden KejadianTidak Diinginkan (KTD) yang dapat merugikan pasien dan juga rumah sakit. Saat ini di rumah sakit walaupun sosialisasi dan pelatihan patient safety sudah dilaksanakan oleh rumah sakit kepada perawat dan petugas kesehatan namun masih ada kasus pasien cedera, jatuh, dan salah pengobatan. Penelitian ini bertujuan untuk mengetahui hubungan kompetensi perawat dalam melaksanakan pengkajian keperawatan, etika keperawatan, pemberian obat dan pengukuran tandatanda vital dengan patient safety di RSUD Piru tahun 2017. Jenis penelitian adalah deskriptif analitik dengan desain cross-sectional. Instrumen yang digunakan adalah kuesioner, dengan sampel 66 orang perawat di RSUD Piru Kabupaten Seram Bagian Barat. Hasil penelitian menunjukan ada hubungan signifikan kompetensi perawat melaksanakan pengkajian keperawatan, etika keperawatan, pemberian obat dan pengukuran tanda tanda vital dengan patient safety, di RSUD Piru. Pengetahuan dan keterampilan teknis perawat tentang patient safety melalui berbagai kegiatan sosialisasi maupun pelatihan harus ditingkatkan agar keselamatan dan keamanan pasien dalam pelayanan di rumah sakit terjamin dan citra rumah sakit menjadi lebih baik.
\end{abstract}

Kata kunci: Kompetensi perawat, patient safety, rumah sakit 


\section{PENDAHULUAN}

Keselamatan pasien merupakan isu global yang paling penting saat ini. Banyak tuntutan pasien atas medical error ketika menjalani perawatan di rumah sakit ${ }^{1}$. Kenyataannya masalah medical error dalam sistem pelayanan kesehatan di rumah sakit mencerminkan fenomena gunung es, karena yang terdeteksi umumnya adalah kejadian yang tidak diinginkan (adverse event) yang ditemukan secara kebetulan saja. Sebagian besar yang lain cenderung tidak dilaporkan, tidak dicatat, atau justru luput dari perhatian.

Berdasarkan laporan dari Komite Keselamatan Pasien Rumah Sakit (KKP-RS) RSUD Piru Kabupaten Seram Bagian Barat (SBB) didapatkan bahwa selama periode 2014-2015, tercatat 10 insiden yang berkaitan dengan keselamatan pasien. Dari jumlah tersebut $4(40 \%)$ adalah medication error, 6 kasus $(60 \%)$ lainnya adalah pasien terjatuh, salah identitas dan lain sebagainya. Sebagian besar insiden tersebut terjadi di Instalasi Rawat Inap3. Program sosialisasi dan pelatihan keselamatan pasien pada seluruh unit pelayanan sudah dilaksanakan di RSUD Piru. Akan tetapi, masih ada kasus pasien cedera, pasien jatuh, salah pengobatan yang mengakibatkan penerapan keselamatan pasien menjadi kurang optimal.

Penyebab utama terjadinya insiden keselamatan pasien oleh perawat di unit rawat inap rumah sakit adalah kurangnya kompetensi perawat4. Kompetensi yang dimiliki oleh perawat menunjang penampilan klinik, sehingga membuat perawat dapat memberikan asuhan yang lebih optimal ${ }^{5}$. Perawat diharapkan mampu bertanggung jawab dan melindungi hak pasien. Salah satu hak yang harus dipenuhi adalah hak memperoleh keamanan dan keselamatan dirinya selama perawatan di rumah sakit ${ }^{6}$. Perawat memiliki konstribusi yang besar dalam keselamatan pasien. Peran kritis perawat professional dalam pencegahan terhadap kesalahan dan kejadian nyaris cedera membawa konsekuensi mengenai perlunya oprimalisasi kompetensi individu perawat ${ }^{5}$. Optimalisasi dilakukan dari aspek kebijakan maupun aspek teknis pelaksanaan asuhan keperawatan.

Penelitian ini dilakukan dengan tujuan untuk mengetahui hubungan kompetensi perawat tentang pengkajian keperawatan, etika keperawatan, pemberian obat dan pengukuran tanda tanda vital dengan patient safety di RSUD Piru.

\section{METODE PENELITIAN}

Desain penelitian yang digunakan adalah penelitian deskriptif analitik dengan desain cross-sectional. Penelitian dilaksanakan di RSUD Piru Kabupaten SBB selama satu bulan. Populasi adalah semua perawat di RSUD Piru Kabupaten SBB. Sampel penelitian ini mengunakan total sampling yaitu 66 responden. Penelitian ini menggunakan kuesioner dan lembar observasi. Pengolahan data menggunakan komputer. Sebelum data dianalisis untuk menjamin kualitas data terlebih dilakukan editing, koding, dan tabulasi.

Analisis bivariat dilakukan menggunakan uji chi-square. Prinsip respect for human dignity, Autonomy, inform consent, respect for privacy and confidentiality, respect for justice and inclusiveness, balancing harms and benefits telah diterapkan dalam penelitian? ${ }^{7}$.

\section{HASIL}

\section{Karakteristik responden}

Berdasarkan Tabel 1 dibawah ini menunjukkan bahwa dari usia pegawai paling banyak $<30$ tahun yaitu 40 responden $(60,6 \%)$, jenis kelamin terbanyak adalah perempuan yaitu 50 responden $(75,8 \%)$, tingkat pendidikan keperawatan terbanyak adalah Diploma III yaitu 34 responden $(51,5 \%)$, status kepegawaian terbanyak adalah PNS yaitu 33 responden (50 \%) dan masa kerja terbanyak $<5$ tahun yaitu 32 responden $(48,5 \%)$.

Tabel 2 menunjukkan bahwa dari 66 orang responden sebagian besar responden mempunyai kompetensi untuk melakukan pengkajian dengan baik yaitu 51 orang $(77,3 \%)$, 
kompetensi aspek etika keperawatan kategori baik lebih banyak yaitu 39 responden $(59,1 \%)$ dan kompetensi dalam pemberian obat kategori baik hampir sebanding dengan kurang baik yaitu 35 responden $(53 \%)$ dan kurang baik 31 responden $(47 \%)$, sedangkan kompetensi melakukan pengukuran tanda tanda vita kategori kurang lebih banyak yaitu 42 responden $(63,6 \%)$.

Tabel 1. Karakteristik responden $(n=66)$ berdasarkan umur, jenis kelamin, tingkat pendidikan, status kepegawaian dan masa kerja di RSUD Piru Kabupaten SBB tahun 2017

\begin{tabular}{lcc}
\hline Usia & Jumlah & $\mathbf{\%}$ \\
\hline$<30$ thn & 40 & 60,6 \\
$31-40$ thn & 18 & 27,3 \\
$41-55$ thn & 8 & 12.1 \\
\hline Jenis Kelamin & & \\
\hline Laki-Laki & 16 & 24,2 \\
Perempuan & 50 & 75,8 \\
\hline Pendidikan & & \\
\hline SPK & 8 & 12,1 \\
DIII & 34 & 51,5 \\
S1 Kep & 18 & 27,3 \\
Ners & 6 & 9,1 \\
\hline Status & & \\
\hline PNS & 33 & 50,0 \\
PTT & 4 & 6,1 \\
Honorer & 29 & 43,9 \\
\hline Masa Kerja & & \\
\hline$<5$ thn & 32 & 48,5 \\
$5-10$ thn & 30 & 45,5 \\
$>10$ thn & 4 & 6,1 \\
\hline Total & $\mathbf{6 6}$ & $\mathbf{1 0 0}$ \\
\hline
\end{tabular}

Tabel 2. Kompetensi perawat di RSUD Piru Kabupaten SBB tahun $2017(n=66)$

\begin{tabular}{lcc}
\hline Kompetensi Pengkajian & Jumlah & \% \\
\hline Baik & 51 & 77,3 \\
Kurang & 15 & 22,7 \\
\hline Kompetensi aspek etika keperawatan & & \\
\hline Baik & 39 & 59,1 \\
Kurang & 27 & 40,9 \\
\hline Kompetensi dalam pemberian obat & \\
\hline Baik & 35 & 53,0 \\
Kurang & 31 & 47,0 \\
\hline Kompetensi perawat melakukan pengukuran TTV & \\
\hline Baik & 24 & 36,4 \\
Kurang & 42 & 63,6 \\
\hline
\end{tabular}


JKT, 2018;9(2):77-86. Kompetensi Perawat dan Patient Safety di RSUD Piru

Irhamdi Achmad

Tabel 3. Patient safety di RSUD Piru Kabupaten SBB tahun $2017(n=66)$

\begin{tabular}{lcc} 
Patient safety & Jumlah & $\%$ \\
\hline Baik & 41 & 62,1 \\
Kurang & 25 & 37,9 \\
\hline Total & 66 & 100 \\
\hline
\end{tabular}

Berdasarkan Tabel 3 tentang penerapan patient safety menunjukkan bahwa dari 66 orang responden sebagian besar memperhatikan patient safety dengan baik yaitu 41 orang $(62,1 \%)$ dan kurang memperhatikan pasien safety hanya 25 orang $(37,9 \%)$

\section{Hubungan kompetensi pengkajian keperawatan dengan patient safety}

Tabel 4. Hubungan kompetensi pengkajian perawat dengan patient safety di RSUD Piru Kabupaten SBB tahun 2017

\begin{tabular}{lccccccc}
\hline \multirow{2}{*}{$\begin{array}{l}\text { Kompetensi aspek } \\
\text { pengkajian }\end{array}$} & \multicolumn{6}{c}{ Baik } & \multicolumn{2}{c}{ Kurang } & \multicolumn{2}{c}{ Total } & \multirow{2}{*}{ p-value } \\
\cline { 2 - 7 } & $\mathrm{n}$ & $\%$ & $\mathrm{n}$ & $\%$ & $\mathrm{n}$ & $\%$ & \\
\hline Kompetensi baik & 33 & 64,7 & 18 & 35,3 & 51 & 100. & \\
Kompetensi kurang & 8 & 53,3 & 7 & 46,7 & 15 & 100. & 0,020 \\
Total & 41 & 62,1 & 25 & 37,9 & 66 & 100. & \\
\hline
\end{tabular}

Berdasarkan Tabel 4 menunjukan bahwa sebanyak 33 orang $(64,7 \%)$ perawat memiliki kompetensi pengkajian kategori baik memperhatikan keamanan dan keselamatan pasien dengan baik, 18 orang $(35,3 \%)$ perawat memiliki kompetensi pengkajian kategori baik tetapi kurang memperhatikan keamanan dan keselamatan pasien. Hasil analisis chi-square nilai $\mathrm{p}=0,020(\mathrm{p}<0, .05)$, artinya ada hubungan signifikan kompetensi pengkajian perawat dengan patient safety.

\section{Hubungan kompetensi perawat aspek etika dengan patient safety}

Berdasarkan Tabel 5 menunjukan bahwa sebanyak 27 orang $(69,2 \%)$ perawat memiliki kompetensi etika keperawatan yang baik memperhatikan keamanan dan keselamatan pasien dengan baik. Hasil analisis didapatkan nilai $\mathrm{p}=0,031(\mathrm{p}<0.05)$, artinya ada hubungan signifikan kompetensi perawat sesuai aspek etika keperawatan dengan patient safety.

Tabel 5. Hubungan kompetensi perawat sesuai aspek etika keperawatan dengan patient safety di RSUD Piru Kabupaten SBB tahun 2017

\begin{tabular}{lccccccc}
\hline \multirow{2}{*}{$\begin{array}{l}\text { Kompetensi aspek } \\
\text { etika keperawatan }\end{array}$} & \multicolumn{6}{c}{ Baik } & \multicolumn{4}{c}{ Kurang } & \multicolumn{2}{c}{ Total } & \multirow{2}{*}{ p-value } \\
\cline { 2 - 7 } & $\mathrm{n}$ & $\%$ & $\mathrm{n}$ & $\%$ & $\mathrm{n}$ & $\%$ & \\
\hline Kompetensi baik & 27 & 69,2 & 12 & 30,8 & 39 & 100 & \\
Kompetensi kurang & 14 & 51,9 & 13 & 48,1 & 27 & 100 & 0,031 \\
Total & 41 & 62,1 & 25 & 37,9 & 66 & 100 & \\
\hline
\end{tabular}


JKT, 2018;9(2):77-86. Kompetensi Perawat dan Patient Safety di RSUD Piru

Irhamdi Achmad

Hubungan kompetensi perawat dalam pemberian obat dengan patient safety

Tabel 6. Hubungan kompetensi perawat dalam pemberian obat dengan patient safety di RSUD Piru Kabupaten SBB tahun 2017

\begin{tabular}{lccccccc}
\hline \multirow{2}{*}{$\begin{array}{c}\text { Kompetensi aspek } \\
\text { pemberian obat }\end{array}$} & \multicolumn{6}{c}{ Baik } & \multicolumn{2}{c}{ Kurang } & \multicolumn{2}{c}{ Total } & \multirow{2}{*}{ p-value } \\
\cline { 2 - 7 } & $\mathrm{n}$ & $\%$ & $\mathrm{n}$ & $\%$ & $\mathrm{n}$ & $\%$ & \\
\hline Kompetensi baik & 23 & 65,7 & 12 & 34,3 & 35 & 100. & \\
Kompetensi kurang & 18 & 58,1 & 13 & 1,9 & 31 & 100. & 0,010 \\
Total & 41 & 62,1 & 25 & 37,9 & 66 & 100. & \\
\hline
\end{tabular}

Berdasarkan tabel 6 menunjukan bahwa 23 orang $(65,7 \%)$ perawat memiliki kompetensi baik dalam pemberian obat dan memperhatikan keamanan dan keselamatan pasien dengan baik, 12 orang $(34,3 \%)$ perawat memiliki kompetensi pemberian obat dengan baik tetapi kurang memperhatikan keamanan dan keselamatan pasien. Hasil Uji chi-square nilai continuity correction didapatkan $p$-value $=0,010(\mathrm{p}<0.05)$, artinya ada hubungan signifikan kompetensi perawat dalam pemberian obat dengan pasien safety.

Hubungan kompetensi perawat pengukuran tanda tanda vital dengan patient safety

Tabel 7. Hubungan kompetensi perawat pengukuran TTV dengan patient safety di RSUD Piru Kabupaten SBB tahun 2017

\begin{tabular}{lccccccc}
\hline \multirow{2}{*}{$\begin{array}{l}\text { Kompetensi aspek } \\
\text { pengukuran TTV }\end{array}$} & \multicolumn{6}{c}{ Baik } & \multicolumn{2}{c}{ Kutient safety } & \\
\cline { 2 - 7 } & $\mathrm{n}$ & $\%$ & $\mathrm{n}$ & $\%$ & $\mathrm{n}$ & $\%$ & Total \\
& 13 & 54,2 & 11 & 33,3 & 24 & 100. & \\
\hline Kompetensi baik & 28 & 66,7 & 14 & 45,8 & 42 & 100. & 0,033 \\
Kompetensi kurang & 41 & 62,1 & 25 & 37,9 & 66 & 100. & \\
Total & 4 & & & & & &
\end{tabular}

Berdasarkan Tabel 7 menunjukan 28 orang $(66,7 \%)$ perawat memiliki kompetensi pengukuran TTV kategori kurang baik namun memperhatikan keamanan dan keselamatan pasien dengan baik, 14 orang $(54,2 \%)$ perawat memiliki kompetensi pengukuran TTV kurang baik dan kurang memperhatikan keamanan dan keselamatan pasien. Hasil Uji chi-square $p=$ $0,033(\mathrm{p}<0.05)$, artinya ada hubungan signifikan kompetensi perawat sesuai aspek pengukuran TTV dengan patient safety.

\section{BAHASAN}

\section{Hubungan kompetensi pengkajian perawat dengan patient safety}

Hasil penelitian menunjukkan ada hubungan signifikan kompetensi pengkajian perawat dengan patient safety, dari 66 orang responden sebagian besar mempunyai kompetensi baik melakukan pengkajian dengan memperhatikan keamanan dan keselamatan pasien yaitu sebanyak $64,7 \%$ dan $35,3 \%$ perawat memiliki kompetensi pengkajian dengan baik tetapi kurang memperhatikan keamanan dan keselamatan pasien dan sebagian perawat memiliki kompetensi pengkajian kurang tetapi memperhatikan keamanan dan keselamatan pasien dengan baik hal ini memberi interpretasi bahwa kebanyakan perawat yang bekerja di RSUD Piru Kabupaten SBB memiliki kompetensi yang cukup tentang patient safety dalam melakukan pengkajian.

Pengkajian merupakan tahap awal dari proses keperawatan. Tahap pengkajian memerlukan kecermatan dan ketelitian untuk mengenal masalah dan keberhasilan proses 
berikutnya sangat bergantung pada tahap ini. Pengkajian yang dilakukan oleh perawat terhadap keselamatan pasien secara terus-menerus mulai awal pasien masuk rumah sakit dan selama perawatan pasien sampai pasien pulang. Dengan demikian pengkajian terhadap keamanan dan keselamatan pasien perlu dilakukan dengan baik karena respon pasien terhadap keadaan sakit berbeda-beda ${ }^{9}$.

Peran dan kontak selama 24 jam terus menerus membuat perawat lebih mengetahui perubahan klinis dan emosi klien serta lebih mengetahui kebutuhan fisik maupun emosional pasien dibandingkan dokter ${ }^{10}$. Hal tersebut mendorong perawat melakukan pengkajian keamanan dan keselamatan pasien secara komprehensif. Satu hal yang dapat dilakukan oleh perawat untuk mencegah KTD beserta dampaknya adalah dengan peningkatan kemampuan perawat untuk melakukan pencegahan dini, deteksi risiko dan koreksi terhadap abnormalitas yang terjadi pada pasien. Peningkatan angka kematian merupakan bagian dari dampak keselamatan pasien membutuhkan peran perawat secara adekuat dalam kondisi emergensi untuk mencegah terjadinya $\mathrm{KTD}^{11}$.

Pengetahuan dan pengalaman perawat dalam melakukan pengkajian yang merupakan proses awal asuhan keperawatan sangat penting untuk diaplikasikan. Sehingga dapat meningkatkan upaya peningkatan keselamatan dan kenyamanan pasien saat dirawat di rumah sakit $^{12}$. Dalam melakukan pengkajian keperawatan, perawat harus memilki pengetahuan tentang ilmu biomedik, ilmu penyakit, ilmu sosial, kultural, dan spiritual. Disamping itu perawat juga harus memilki keterampilan pemeriksaan fisik secara baik serta keterampilan teknis penunjang lainnya. Sehingga perawat lebih cermat untuk melihat faktor potensial yang menyebabkan gangguan keselamatan dan keamanan pasien selama menjalani perawatan di rumah sakit

Keselamatan pasien dalam pelayanan keperawatan berarti terhindarnya pasien dari berbagai kondisi yang dapat merugikan atau membahayakan pasien dalam pelayanan. Berbagai kondisi baik yang bersumber dari faktor internal (pasien) maupun faktor eksternal dapat menjadi faktor resiko yang menimbulkan asuhan yang tidak aman dalam pelayanan keperawatan ${ }^{13}$.

\section{Hubungan kompetensi perawat sesuai aspek etika keperawatan dengan pasien safety}

Hasil penelitian menunjukan hubungan signifikan antara kompetensi perawat sesuai aspek etika keperawatan dengan patient safety. Sebanyak 69,2\% perawat memiliki kompetensi etika keperawatan yang baik memperhatikan keamanan dan keselamatan pasien dan $30,8 \%$ perawat memiliki kompetensi etika keperawatan baik tetapi kurang memperhatikan keamanan dan keselamatan pasien. Hal ini membuktikan bahwa kompetensi sesuai aspek etika memiliki peran yang sangat penting karena pertimbangan pengambilan keputusan terhadap keamanan dan keselamatan pasien (patient safety).

Hasil penelitian ini sejalan dengan penelitian yang dilakukan oleh Mulyani (2013) mengenai analisis penyebab insiden keselamatan pasien oleh perawat di unit rawat inap pada sebuah rumah sakit di Jakarta, didapatkan bahwa faktor yang yang paling berpengaruh terhadap terjadinya insiden keselamatan pasien di rumah sakit ialah kompetensi perawat ${ }^{4}$.

Upaya tenaga kesehatan untuk tidak membahayakan dan merugikan pasien yang telah mempercayakan penanganan kesehatannya terhadap tenaga kesehatan dan rumah sakit dengan didasari oleh standard dan kode etik professional yang harus ditaati, berhubungan dengan keterkaitan berbagai upaya untuk memenuhi hak pasien atas keamanan dan keselamatan, hak atas informasi, hak untuk memilih pelayanan yang diperoleh ${ }^{14}$.

Kompetensi perawat terkait aspek etika keperawatan merupakan kemampuan perawat berperan serta dalam proses pertimbangan, pengambilan keputusan melakukan tindakan keperawatan terhadap pasien dalam pelayanan asuhan keperawatan dan pendampingan pengambilan keputusan tindakan keperawatan atas persetujuan pasien atau keluarga ${ }^{5}$. Berdasarkan Permenkes 1691 tahun 2011, aspek etika keperawatan terhadap keselamatan pasien di rumah sakit sebagai pedoman bagi penerapan keselamatan pasien di rumah sakit. 
Salah satu unsur utama etika keperawatan adalah advocay. Advocacy berarti melindungi. Melindungi pasien supaya selamat selama berada dalam asuhan keperawatan pasien. Advocacy dapat dilakukan dengan cara menjamin intervensi yang diberikan perawat agar selalu aman. Hal ini dapat diperoleh bila perawat memberikan asuhan keperawatan sesuai dengan kompetensi yang dimilikinya. Bila perawat tidak memiliki kompetensi, maka ia tidak layak diberi penugasan untuk intervensi tersebut ${ }^{20}$.

Karakter perawat yang baik juga dapat dirujuk kepada teori Carol Gilligan yaitu Truth. Truth merupakan suatu karakter yang terpuji, dimana perawat bertanggung jawab penuh terhadap intervensi keperawatan yang diberikan. Perawat akan melihat kepentingan pasien dan bagaimana kepentingan ini dapat dipenuhi. Bila prinsip-prinsip etik ini dapat dipenuhi maka pasien merasa aman ditangan perawat dan perawat menunjukkan profesi muliannya pada pasien dan masyarakat. Prinsip lain Beneficence merupakan suatu kegiatan yang membawa kebaikan untuk pasien atau lebih dikenal dengan doing good. Sedangkan nonmaleficence adalah kegiatan yang tidak mencelakakan pasien dan dikenal dengan do no harm $^{20}$.

Persatuan Perawat Nasioanal Indonesia menguraikan kompetensi sebagai kemampuan yang dimiliki seseorang untuk melakukan suatu pekerjaan yang didasari oleh pengetahuan, ketrampilan dan sikap sesuai dengan petunjuk kerja yang ditetapkan serta dapat terobservasi ${ }^{5}$. Dalam kerangka kerja International Council of Nursing, kompetensi perawat dikelompokkan menjadi tiga ranah utama yakni praktek profesional etis, pemberian manajemen asuhan keperawatan dan pengembangan kualitas personal perawat ${ }^{15}$. Dimana ketiga ranah kompetensi ini mencerminkan pengetahuan, serangkaian ketrampilan kognitif, teknikal atau psikomotor serta sikap dan kepribadian ${ }^{8}$.

Perawat diharapkan mampu bertanggung jawab dan melindungi hak pasien. Berdasarkan UU No. 44 Tahun 2009 pada pasal 32 tentang rumah sakit, salah satu hak yang harus dipenuhi adalah hak memperoleh keamanan dan keselamatan dirinya selama perawatan di rumah sakit. Perawat memiliki konstribusi yang besar dalam keselamatan pasien. Peran kritis perawat professional dalam pencegahan terhadap kesalahan dan kejadian nyaris cedera membawa konsekuensi mengenai perlunya optimalisasi perkembangan individu perawat.

Hal ini didukung bahwa hal yang berpengaruh terhadap kehidupan organisasi untuk meningkatkan mutu melalui aspek keselamatan pasien dipengaruhi oleh faktor individu ${ }^{16}$. Hal ini berarti bahwa optimalisasi perkembangan individu perawat memerlukan upaya peningkatan dan ketrampilan secara khusus dalam lingkup keselamatan pasien.

\section{Hubungan kompetensi perawat melakukan pemberian obat dengan patient safety}

Hasil penelitian ini menunjukan bahwa ada hubungan yang signifikan antara kompetensi perawat sesuai aspek pemberian obat dengan patientsafety, dan analisa data diperoleh $65,7 \%$ perawat memiliki kompetensi pemberian obat dengan baik memperhatikan keamanan dan keselamatan pasien, sedangkan $34,3 \%$ perawat memiliki kompetensi pemberian obat dengan baik tetapi kurang memperhatikan keamanan dan keselamatan pasien dan sebagian perawat memiliki kompetensi pemberian obat kurang tetapi memperhatikan keamanan dan keselamatan pasien dengan baik.

Hasil penelitian ini sejalan dengan penelitian lain terkait keselamatan pasien dari perspektif pasien yang dilakukan oleh Maryam (2009) di unit rawatinap RS bahwa faktor yang paling berhubungan dengan kepuasan pasien dalam penerapan keselamatan pasien adalah akurasi dalam pemberian obat ${ }^{17}$.

Peningkatan keamanan obat yang perlu diwaspadai (high alert) dalam sasaran keselamatan pasien terjadi bila obat-obatan menjadi bagian dari rencana pengobatan pasien, manajemen harus berperan secara kritis untuk memastikan keselamatan pasien ${ }^{18}$. Obat-obatan yang perlu diwaspadai (high alert medication) adalah obat yang sering menyebabkan terjadi kesalahan/kesalahan serius (sentinelevent), obat yang berisiko tinggi menyebabkan dampak yang tidak diinginkan (adverse event) seperti obat-obatan yang terlihat mirip (Nama Obat 
Rupa dan Ucapan Mirip/NORUM), obat-obatan yang sering disebutkan dalam isu keselamatan pasien adalah pemberian elektrolit konsentrat secara tidak sengaja (misalnya, kalium klorida $2 \mathrm{meq} / \mathrm{ml}$ atau yang lebih pekat, kalium fosfat, natrium klorida lebih pekat dari $0,9 \%$, dan magnesium sulfat $50 \%$ atau pekat $)^{13}$.

Kesalahan ini bisa terjadi bila perawat tidak mendapatkan orientasi dengan baik di unit pelayanan pasien, atau bila perawat kontak tidak diorientasikan terlebih dahulu sebelum ditugaskan, atau pada keadaan gawat darurat. Cara yang paling efektif untuk mengurangi atau mengeliminasi kejadian tersebut adalah dengan meningkatkan proses pengelolaan obatobatan yang perlu diwaspadai termasuk memindahkan elektrolit konsentrat dari unit pelayanan pasien ke farmasi ${ }^{19}$.

Kompetensi perawat dalam melakukan pemberian obat yang baik pada pasien terjadi karena berbagai pengalaman, orientasi di unit pelayanan, pengelolaan obat secara teratur dengan prinsip $5 \mathrm{~B}$ dan pengetahuan yang dimiliki oleh perawat, sehingga pelaksanaan kompetensi dalam pemberian obat juga menjadi tanggung-jawab perawat secara mennyeluruh terutama terhadap keamanan dan keselamatan pasien.

\section{Hubungan kompetensi perawat melakukan pengukuran tanda tanda vital dengan patient safety}

Hasil penelitian menunjukan ada hubungan yang signifikan antara kompetensi perawat sesuai aspek pengukuran TTV dengan patient safety. Sesuai analisis data $66,7 \%$ perawat kurang memiliki kompetensi pengukuran TTV, namun memperhatikan keamanan dan keselamatan pasien dengan baik, 54,2\% perawat memiliki kompetensi pengukuran TTV dengan baik memperhatikan keamanan dan keselamatan pasien dan sebagian perawat memiliki kompetensi pengukuran TTV baik tetapi kurang memperhatikan keamanan dan keselamatan pasien dengan baik.

Vital sign atau tanda-tanda vital adalah ukuran statistik berbagai fisiologis yang digunakan untuk membantu menentukan status kesehatan seseorang, terutama pada pasien yang secara medis tidak stabil atau memiliki faktor-faktor risiko komplikasi kardiopulmonal dan untuk menilai respon terhadap intervensi ${ }^{21}$. Kegunaan dari pengukuran tanda-tanda vital bisa dijadikan data yang akan menunjukan status kesehatan menjadi indikator fungsi dasar tubuh yaitu menilai kesehatan fisik umum, mengidentifikasi adanya gangguan medis akut, mendeteksi apabila ada kemungkinan penyakit kronis, mengukur seberapa baik tubuh bisa mengatasi stress fisiologis dan menunjukkan kemajuan terapi perawatan ${ }^{22}$. Pemeriksaan tanda tanda vital (TTV) merupakan metode pengukuran atau pemeriksaan fungsi tubuh yang paling dasar yang dapat dilakukan untuk mengetahui tanda klinis yang memiliki manfaat dalam menegakan diagnosis penyakit dan menentukan perencanaan terapi yang tepat ${ }^{22}$.

Keselamatan pasien dalam pelayanan kesehatan terutama tindakan keperawatan termasuk pengukuran TTV berarti terhindarnya pasien dari berbagai kondisi yang dapat merugikan atau membahayakan pasien dalam pelayanan keperawatan. Berbagai kondisi baik yang bersumber dari faktor internal (pasien) maupun faktor eksternal dapat menjadi faktor risiko yang menimbulkan kondisi resiko cedera pasien dalam pelayanan keperawatan ${ }^{3}$.

Dengan demikian masalah keamanan dan keselamatan pasien di rumah sakit perlu diperhatian secara berkesinambungan walaupun sosialisasi dan pelatihan sudah dilaksanakan tetapi masih ada kasus pasien cedera, pasien jatuh, salah pengobatan, yang mengakibatkan penerapan keselamatan pasien menjadi kurang optimal, sehingga diperlukan langkah-langkah yang lebih konkrit dalam penerapan program keselamatan pasien.

Oleh karena itu perlu adanya upaya peningkatan kompetensi perawat untuk memberikan pelayanan asuhan keperawatan yang bermutu. Pihak RSUD Piru diharapkan tetap meningkatkan pengetahuan dan ketrampilan perawat tentang pasien safety melalui berbagai kegiatan sosialisasi maupun pelatihan sehingga pelayanan patient safety terjamin, citra rumah sakit menjadi lebih baik. 
JKT, 2018;9(2):77-86. Kompetensi Perawat dan Patient Safety di RSUD Piru

Irhamdi Achmad

\section{SIMPULAN}

Terdapat hubungan signifikan antara kompetensi pengkajian keperawatan, etika perawat, pemberian obat dan pengukuran tanda tanda vital dengan patient safety di RSUD Piru.

\section{SARAN}

Diharapkan kepada pengambilan kebijakan di rumah sakit maupun pemerintah Kabupaten SBB agar dapat memfasilitasi perawat di rumah sakit untuk meningkatkan kompetensi teknis dan sikap profesional melalui pelatihan pelatihan yang relevan.

\section{UCAPAN TERIMA KASIH}

Ucapan terima kasih disampaikan kepada Bupati, Dinas Kesehatan Kabupaten SBB, Direktur RSUD Piru Kabupaten SBB yang telah mengizinkan peneliti untuk melaksanakan penelitian di RSUD Piru Kabupaten SBB serta para responden yang telah bekerjasama dalam penelitian ini. Ucapan terimakasih juga disampaikan kepada Direktur Politeknik Kesehatan Kemenkes Maluku yang telah mengizinkan saya untuk melaksanakan penelitian.

\section{RUJUKAN}

1. Aditama TY. Manajemen administrasi rumah sakit (Edisi 2). Jakarta: UI-Press; 2006.

2. Silvia. Hubungan Kompetensi Perawat dengan Penerapan Keselamatan Pasien dalam Asuhan Keperawatan di Ruang Rawat Inap RSUP Prof. Kandou Manado [Tesis]. Makassar: Uiversitas Hasanuddin; 2017.

3. Kesehatan dan Keselamatan Pasien. Panduan nasional keselamatan pasien rumah sakit. Jakarta: Depkes RI; 2008.

4. Mulyani DS. Analisis penyebab insiden keselamatan pasien oleh perawat di Unit Rawat Inap Rumah Sakit X Jakarta [Tesis]. Fakultas Kesehatan Masyarakat Universitas Indoensia; 2013.

5. Persatuan Perawat Nasional Indonesia. Standar profesi dan kode etik perawat Indonesia. Jakarta: PPNI; 2010.

6. Reason, J. KelalaianManusia: modus dan manajemen. BMJ. 2012;320(7237): 768770U.

7. Nursalam. Konsep dan Penerapan Metodologi Penelitian Ilmu Keperawatan. Ed 2. Salemba Medika: Jakarta; 2011.

8. Potter PA, Perry AG. Buku ajar fundamental keperawatan: Konsep, proses dan praktik edisi 4. Jakarta: EGC; 2005.

9. Prawitasari S. Hubungan beban kerja perawat dengan keselamatan pasien di RS H Jakarta [Tesis]. Fakultas Ilmu Keperawatan Universitas Indonesia; 2009.

10. Cahyono JB. Membangun budaya keselamatan pasien dalam praktik kedokteran. Yogyakarta: Penerbit Kanisius; 2008.

11. Diah G Arumaningrum. Tingkat Pengetahuan Perawat tentang Patient Safety di Unit Anak RS PKU Muhammadiyah Bantul, RS PKU Muhammadiyah Yogyakarta Unit I dan RS PKU Muhammadiyah Yogyakarta Unit II [Skripsi]. Fakultas Kedokteran dan Ilmu Kesehatan Universitas Muhammadiyah Yogyakarta; 2014.

12. Yahya AA. Konsep dan program patient safety. Disampaikan pada Konvensi Nasional Mutu RS Ke VI Bandung; 2010.

13. Departemen Kesehatan. Panduan nasional keselamatan pasien rumah sakit (patientsafety). Jakarta: Depkes RI; 2010.

14. Emslie S. Perspektif Internasional tentang patient safety [Internet]; 2014 [cited 29 December 2017]. Available from: http://www.nao.org.uk/idoc.

15. International Council of Nurse. hari perawat Internasional, staf yang Aman dan menyelamatkan hidup: informasi dan tindakan alat kit [Internet]; 2009[cited 29 December 2017]. Available from: http://www.icn.ch.

16. Lumenta NA.Seni dari negara patient safety. Jakarta: EGC; 2010.

17. Maryam D. Hubungan penerapan tindakan keselamatan pasien oleh perawat pelaksanan dengan kepuasan pasien di irna bedah dan irna medik RSUD S Surabaya [Tesis]. Fakultas Ilmu Keperawatan Universitas Indonesia; 2009. 
JKT, 2018;9(2):77-86. Kompetensi Perawat dan Patient Safety di RSUD Piru

Irhamdi Achmad

18. WHO. Solusi hidup hemat patient safety;2012 [cited 29 December 2017]. Available from: http://www.who.int.

19. AHRQ. Publikasi No. 07-E005. Rocckville, MD: Agen Untuk Kesehatan dan Penelitian Kualitas; 2013.

20. Dewan Pengurus Pusat Persatauan Perawat Nasional Indonesiua. Pedoman Perilaku Sebagai Penjabaran Kode Etik Keperawatan. Penerbit DPP PPNI. Jakarta: 2017.

21. UNHAS. Pemeriksaan vital sign [Internet]; 2016 [cited 3 Januari 2019] Available from: https:// med. unhas.ac.id

22. Dokter Sehat.Pemeriksaan Tanda Tanda Vital dan Nilai Normal [Internet]; 2018 [cited 3 Januari 2019] Available from: https://doktersehat.com

23. Mediskus. Tanda Tanda Vital Pemeriksaan dan Nilai Normal [Internet]; 2019 [cited 3 Januari 2019] Available from:https://mediskus.com. 